\title{
Digital publishing and the new era of digital divide
}

\author{
Allam Ahmed \\ SPRU - Science and Technology Policy Research \\ The Freeman Centre, University of Sussex \\ Brighton BN1 9QE, UK \\ Fax: +44 (0) 1273685865 \\ E-mail: allam.ahmed@sussex.ac.uk
}

\begin{abstract}
The scarcity of literature in educational institutions is a serious problem in different parts of the world, particularly in developing countries where there is a real need for better access to information. It is vitally important that the technological gap between developing and developed countries is narrowed, and scientific journals have a key role to play in ensuring that this takes place. This paper aims to assess and evaluate Digital Publishing (Open Access Publishing and Open Source Models) as a proposed solution to avoid restrictions on accessing scientific knowledge, particularly in the developing countries. More importantly, the paper outlines opportunities and challenges of open-access publishing for the developing countries. However, oftentimes there are mismatches between what the 'donor' countries can reasonably offer and what the developing countries can implement.
\end{abstract}

Keywords: digital publishing; digital divide; open access publishing; open source; Developing Countries (DCs); Information and Communication Technology (ICT); knowledge transfer; Science and Technology (S\&T); globalisation; Sustainable Development (SD).

Reference to this paper should be made as follows: Ahmed, A. (2005) 'Digital publishing and the new era of digital divide', Int. J. Learning and Intellectual Capital, Vol. 2, No. 4, pp.346-363.

Biographical notes: Allam Ahmed holds a PhD in Technology Transfer with background in economics, management, marketing, and science. He is Full Member and Chartered Marketer of the Chartered Institute of Marketing, UK. Allam has won several international awards, including the RAC College Scholarship and Book Prize for Best MBA/MSc Dissertation. Published widely on technology transfer, management and policy with particular focus on the developing countries in a wide range of national and international academic journals and books. Ahmed is Founding Editor of WRSTSD and WREMSD, and serves on the Editorial Board of five international journals in business, entrepreneurship, marketing, management, strategy, and international business. With substantial experience in research and teaching in Africa, Europe, and the Middle East, Ahmed has consulted for several leading public and private institutions and worked with international organisations. 


\section{Introduction}

Following a recent report by the UK House of Commons Science and Technology Committee (STC, 2004) published last year, entitled 'Scientific publications: free for all?' Southampton University is the first UK university to announce early this year (2005) that it will make all of its academic and scientific output available for free and that its repository will be an integral part of its research infrastructure in the future (for more details, see MacLeod, 2005). The STC report recommends that all UK higher education institutions establish institutional repositories to make all their published output available online free of charge and for the Government to formulate a strategy for future action as a matter of urgency.

Knowledge is the chief currency and the essence of modern age. It can also be a strategic resource and a lifeline for the sustainable development of developing countries (Hamel, 2004). Whilst libraries in the developed world are struggling to purchase access to all the scientific publications they need, subscriptions are prohibitively expensive for institutions in the developing world. This could eventually lead to an increasing marginalisation of science and scientists in poorer countries, with a growing gulf in technological proficiency and economic development between rich and poor. UNESCO's 32nd General Conference in 2003 focused on 'Building knowledge societies and advancement of knowledge-based practices' as an essential component of globalisation and sustainable economic growth, particularly in developing countries. Moreover, science is a public good and everyone who requires knowledge in a given area has the right to attain it. Governments spend vast amounts on scientific research; yet, majority of the articles reporting the results of this valuable investment is locked in archives, which only give access to paying subscribers. As a result, restricting access to knowledge restricts the development of science and has severe effects on the general well-being of people. A current example of how knowledge sharing can accelerate development in science and benefit people has been experienced in the case of Severe Acute Respiratory Syndrome (SARS) epidemic during which the Human Genome Project data were made available to scientists to turn a collection of individual sequences into an incomparably richer resource. ${ }^{1}$

According to recent reports by the STC (2004) and The Wellcome Trust (2003), the average price of an academic journal rose by $58 \%$ between 1998 and 2003, compared to a UK retail price index increase of $11 \%$ over the same period. For the different period between 1990 and 2000, Blackwell's Periodical Price Indexes show an increase in average journal price of $184.3 \%$ in medical journals and $178.3 \%$ in science and technology journals. The situation is very similar in the USA; as indicated by the Association of Research Libraries, serials subscription prices in US dollars rose $207 \%$ between 1986 and 1999 (Shulenburger, 2001).

These substantial price increases have been attributed mostly to the recent publisher mergers such as the Pergamon-Elseiver and the Kluwer-Lippincott mergers. As libraries come under increasing financial pressure from inflated subscription fees and decreasing bargaining power against the dominant powerful publishers that push forward their 'bundled' products, open-access publishing model has become the new hope that can provide free knowledge to everyone who has access to the internet. Although the model still has a long way to go in terms of finding solutions for financing of online articles for publication, there is great hope for freeing the publishing and making scientific knowledge available to a much larger community base. 


\section{Traditional publishing}

According to Tenopir and King (2000) the traditional publishing activities mainly incur article-processing costs (which is according to the number and the size of the articles handled) in addition to journal reproduction and distribution costs, which depend on the number of subscribers, frequency of publication, and the size of the journal. The fixed costs, usually called the publishing support costs, such as marketing and administration costs, come over the variable costs and are not affected by the number of subscriptions. Although gross margins for journals are around 35\%, revenue and cost data for journal publishing depend heavily on subject matter, circulation (scale economies), and ability to attract advertising (The Wellcome Trust, 2003; UKDTI, 2002). Typical income and costs for a journal are illustrated in Table 1 below. However, there are significant differences between Science/Technology/Medicine (STM) journals and Humanities/Social Science (HSS) journals.

Table 1 Typical costs and income of a journal as percentage (\%) of total

\begin{tabular}{lrrlrr}
\hline Costs & \multicolumn{5}{c}{ Revenues } \\
\hline Items & SMT & \multicolumn{1}{c}{ HSS } & Items & STM & HSS \\
\hline Production & 58 & 56 & Subscriptions & 85 & 74 \\
Postage & 6 & 7 & Single copy/back volumes & 6 & 2 \\
Distribution & 2 & 2 & Advertising/mailing lists & 5 & 2 \\
Total & 66 & 64 & Offprints/reprints & 1 & 8 \\
Gross margin & 34 & 36 & Permissions & 1 & 0 \\
& & & Page charges/submission fees & 0 & 12 \\
& & & Others & 100 & 0 \\
& & & Total & 100 \\
\hline
\end{tabular}

Source: Adopted from Page et al. (1997) in The Wellcome Trust (2003) Table 3.1, p.13 and UKDTI (2002) Table 6.5, p.37

Price inflation of academic journals is a great concern for the academic environments, especially considering the existing and potential impacts on university libraries and the academic research staff in both developed and developing countries. The Chartered Institute of Library and Information Professionals (CILIP) reported that between 1996-1997 and 2000-2001 the information resource budget of UK university libraries has decreased by $29 \%$ in real terms, whilst the average journal price over the same period increased by $41 \%$ (STC, 2004).

According to Cetto (2001) there is a $43.7 \%$ decline in total journal subscriptions for 38 university libraries in Australia between 1993 and 1998. During one recent year, 24 Canadian libraries cancelled $\$ 4.34$ million (Canadian) in journal subscriptions. Several studies by McCabe $(2004 ; 2002)$ indicate that the sensitivity of library demand to price increases is very small by normal standards (a $1 \%$ increase in price results in a $0.3 \%$ decline in subscriptions), which gives the merging firms the possibility to fully exercise their increased market power and inflate the prices. On the other hand, other scholars suggest that mergers may not be a significant determining factor on the increasing costs of publishing as each title has its own distinct market, and owners of these individual 
titles already have the capacity to achieve monopoly returns. The corollary of this argument is that mergers do not matter. He also adds the possibility that even though the overlapping titles merge, they cannot grab a share large enough to ruthlessly exercise price control in the publishing sector considering variety of disciplines covered by different journals.

\section{Digital publishing}

Traditional publishing, which used to be the method of communication among scholars, does not anymore provide the necessary facilities for scientists' works to be available for the growing number of masses who demand faster, easier, and cheaper access to scientific knowledge. This specific demand, coupled with the rapidly changing knowledge body, has led to a shift towards digital publishing which gave the authors the chance to publish their work on the internet, which is accessible to a majority of science communities all over the world. Digital publishing has not only increased the overall accessibility of scholarly publications but also created a foothold for the economic development of developing countries provided that the knowledge is equally accessible as it is hosted by the internet.

Facing the increasing costs and monopolistic approaches to scholarly publishing, many initiatives have been started to realise the open-access publishing model, which will benefit the whole science society by increasing the availability of access to knowledge and decreasing the overall publishing costs by breaking the monopoly power of publishers in the industry. However, despite the hopes and optimism over the digital publishing, recent years have shown that traditional publishers have found ways of adapting the traditional profit-making-process path to digital publishing process. Publishers charge online subscription fees in return for providing access to scientific journals, articles, or a bundle of these. In this context, libraries are made to agree to the deal known as 'Big Deal', which means buying electronic access to all the journals of a commercial publisher (Frazier, 2001). This 'one size fits all' approach leaves the libraries under harsh pressure since they are made to pay also for the nonrequired components of the bundle to be able to purchase the necessary components.

According to Professor Suber's (2005) Timeline of the Open Access Movement, the international movement of open-access publishing started in 1966 when the US Department of Education's Office of Educational Research and Improvement and the National Library of Education launched the Educational Resources Information Center (ERIC). Since then, the movement towards open access has been going from strength to strength. However, there are several major developments that took place in the last two years involving different key international bodies including: the first two open-access journals by the Public Library of Science; the UK Joint Information Systems Committee; ${ }^{2}$ the Bethesda Statement on Open Access Publishing; the introduction of the Public Access to Science Act into the US Congress; ${ }^{3}$ the Howard Hughes Medical Institute; The Wellcome Trust support of open-access publishing; the Berlin Declaration on Open Access to Knowledge in the Sciences and Humanities; ${ }^{4}$ and even the United Nations World Summit on the Information Society (2003), which endorsed open access in its declaration of principles and plan of action. 


\subsection{Open-access publishing}

The Bethesda meeting on Open Access Publishing (11 April 2003) defined 'Open Access Publication' as one that meets the following two conditions:

- The author(s) and copyright holder(s) grant(s) all users a free, irrevocable, worldwide, perpetual right of access to, and a license to copy, use, distribute, transmit and display the work publicly and to make and distribute derivative works in any digital medium for any responsible purpose, subject to proper attribution of authorship, as well as the right to make small numbers of printed copies for their personal use.

- A complete version of the work and all supplemental materials, including a copy of the permission as stated above, in a suitable standard electronic format is deposited immediately upon initial publication in at least one online repository that is supported by an academic institution, scholarly society, government agency, or other well-established organisation that seeks to enable open access, unrestricted distribution, interoperability, and long-term archiving (for the biomedical sciences, PubMed Central is such a repository).

In this definition, the idea that dissemination of scientific discoveries and ideas provides the further foundation for progress in science, makes the model justifiable from a community point of view. In addition, it can be easily argued that removing barriers in front of access to knowledge will provide further benefits for the whole society; from the author's point of view, increased access will provide increased impact for the work and good reputation for the author. Open-access publishing will definitely provide means to break the publisher monopoly and release the pressures on the academic community.

Open-access publishing aims to provide free online access to all journals in which case readers will not be asked to pay for subscription fees and therefore increase the mass audience an article can reach and thus promote further creation of knowledge. The extent of constructive discussions over issues which will contribute to establishment of fresh ideas and theories will definitely be enlarged as the communication becomes cheaper, easier, and rapid over the internet.

\subsection{Open-Source Knowledge}

Meanwhile, Open-Source Knowledge (OSK) means open technical standards and open forms of technical infrastructures, network technologies, computer architectures, system software, and generic drug (for more details, see Hamel, 2004; Weerawarana and Weeratunga, 2004). In the case of software it means free-of-charge access to coded knowledge open to modification, adaptation, and further innovation. This is necessary in order to prevent the formation of inefficient monopolies and possibly exorbitant economic rent. In the case of biotechnology it means access to basic biotechnological tools. OSK is the object of a political movement particularly dedicated to free operating systems to lessen the dominance of Windows and eventually to replace it. In this area, only time will tell if various technological standards that would emerge from OSK will be superior to a few but more regulated monopolistic universal standards. Free products in the area of software usually have a catch and are usually actively promoted behind the scene by powerful corporate interests. It is the case with Linux - the main competitor of 
Windows. A bitter judiciary dispute is now engaged between contributors to Linux, including IBM and developers of UNIX, and their distributors, including particularly SCO Inc., over who owns what in Linux (Hamel, 2004). Therefore it is imperative not to be too naïve in this area and to be careful not to fall into costly traps under the appearance of free products. What is bad and must be fought is the monopolised control of technical infrastructures, via proprietary knowledge, that has the power of setting standards restricting the freedom of developers and users.

\section{$3.3 \quad$ Funding}

Financial constraints over funding free online publishing have been threatening the feasibility of the open-access publishing model. Main concerns concentrate on the question of 'who pays it' and the solutions suggest it might be the authors, institutions like universities and research centres, or granting institutions which have a stake in the development of knowledge. There are several problems with regard to financing open-access publishing.

First of all, it should be made clear that open access does not mean there are no costs involved. As stated by Savenije (2003), open access means, "the reader does not pay the costs" yet the question of "who pays for it" remains. According to different studies (see Savenije, 2003), there is not a great difference between the financing of traditional publishing model and the financing of open-access publishing model: In traditional model, the readers pay for the costs of publishing as well as the profits made by the publisher, whereas in the open-access model the institutions pay for the overall publishing costs in the name of the readers and the authors. However, in the latter case, the publisher need not be a profit-oriented agent, thus the overall costs may be lower than the traditional publishing costs. However, the most desired solution is to grant support from research sponsors and other funding bodies that have an interest in the dissemination of knowledge. ${ }^{1}$ This solution borrows from the idea that science is a public good and should not be totally left into the hands of the private sector. Obviously, existing externalities in the case of knowledge creation and accumulation make it difficult for private bodies to provide knowledge on only-cost basis. Moreover, the current situation where publishers charge large subscription fees due to high profit margins indicates an undesirable situation for the public efficiency where access to knowledge is prohibited. Thus, as a solution, preferably, government agencies need to participate in the open-access publishing model and provide necessary funding for the publication or subsidise universities and research organisations to pay for the costs of open-access model.

\section{Digital divide}

Dynamic information infrastructure is one of the key pillars of the knowledge economy as identified by the World Bank, and infrastructure is a very important determinant of national competitive advantage (Porter, 1990). Therefore, Information and Communication Technologies (ICTs) are crucial for the knowledge-based society of the future and the nucleus of the globalised economy. 
The transfer of information and knowledge from developed to developing countries is one important source of support for sustainable development under current conditions and there is, in the recent time, an overwhelming evidence for the disparity in scientific output between the developing and the already developed countries (Cetto, 2001; Gibbs, 1995; May, 1997; Goldemberg, 1998; Riddoch, 2000). It is not necessary to recall that a small group of countries comprising $20 \%$ of humanity account for over $90 \%$ of the internationally recognised scientific production (see Table 2). These countries are also the more technologically advanced and are therefore at great advantage when it comes to publishing and distributing the results of their scientific production. Scientists who are not connected to the net are excluded automatically from publishing in a growing number of journals.

Table 2 World mainstream scientific publications by regions or large countries

\begin{tabular}{lc}
\hline Region or country & Publications (\%) \\
\hline Europe & 37.5 \\
North America & 36.6 \\
Industrialised Asia & 10.8 \\
CIS & 3.7 \\
China & 2.0 \\
India & 1.9 \\
Latin America & 1.8 \\
Sub-Saharan Africa & 0.7 \\
World & 100 \\
\hline
\end{tabular}

Source: Adopted from Cetto (2001)

Recent UNESCO estimates indicated that, in 1997, the developed countries accounted for some $84 \%$ of the global investment in scientific research and development, had approximately $72 \%$ of the world researchers, and produced approximately $88 \%$ of all scientific and technical publications registered by the Science Citation Index (SCI) (UNESCO, 2001). Imperfect as the prevailing model of 'donor' and 'recipient' countries may be, most developing countries in practice rely on literature produced in developed countries for up-to-date S\&T-related information. Around 60\% of the total world output relating to Science and Technology (S\&T) was produced by only 11 industrially developed countries (UNESCO, 1992). North America and Europe clearly dominate the number of scientific publications produced annually, with $36.6 \%$ and $37.5 \%$, respectively, worldwide. These statistics notwithstanding, more than $80 \%$ of the world consists of developing countries, which encompass $24.1 \%$ of the world's scientists and $5.3 \%$ of its research expenditure. However, these countries only show a participation of $2 \%$ in the indexed output of scientific information. On the basis of national statistics compiled by organisations such as UNESCO and the OECD, certain authors have emphasised the shortcomings of the research systems in developing countries and the shortage of available resources. Some of these authors have also matched socioeconomic conditions against the level of scientific development to conclude that science is yet at its earliest start (Dunn, 1982; Eisemon and Davis, 1991). 


\section{ICT infrastructure}

Technological infrastructures, particularly IT infrastructures, differ in developed and developing countries, requiring innovation not only in knowledge management systems in developing countries but also in achieving compatibility between systems in developing countries and in the developed world. It is estimated that over the next decade, $30 \%$ of the world's economic growth and $40 \%$ of all new jobs will be IT-driven (Vinay and Saran, 1998). For developing countries, keeping up with these changes, and involvement in research, are both vital. Today, countries are increasingly judged by whether they are information-rich or information-poor. Most developing countries particularly SSA recognise that much of their economic future will depend upon the understanding of the global technological forces at work and their long-term implications. However, the evidence also shows that the benefits accrued from the utilisation of ICTs over the recent years have been inequitably distributed with the developing countries facing the prospect of being marginalised. This marginalisation has afflicted a new form of poverty, information poverty, within these countries. The world is beginning to divide between the information rich and the information poor nations (Ahmed, 2004). Walsham (2000) argues that the industrialised countries of the world have been dominant in the production, development, and transfer of information technology, and their interest in the use of IT/S in the developing countries has often been more concerned with the profitability of their own business enterprises than with any broader goals concerning the development of the receiving countries. Therefore, developing countries are posed with the challenge of either becoming an integral part of the knowledge-based global culture or facing the very real danger of finding themselves on the wrong side of the digital divide.

Further, the new ICT products and applications are frequently designed in ignorance of developing countries' realities and fail to address the needs of the most disadvantaged sections of the community (United Nation Commission for Science and Technology, 1998). As pointed out by Arunachalam (2000), the gulf in the levels of science and technology between the developed and the developing countries will tend to widen further with the rapid expansion of the internet in the West and the speedy transition to electronic publishing, and this can lead to increased brain drain and dependence on foreign aid of a different kind (knowledge imperialism). Castells (1998) provides evidence and argues that the use of information technology in the developing countries is deeply implicated in the processes of social exclusion and that the 'fourth world', defined as including the areas of social deprivation in the developing countries, is increasing in size. The risks for developing countries are greater simply because they are less developed and are faced with the prospect of having to integrate advanced technologies whilst their economic development and infrastructure are not yet mature. The workers in these countries are susceptible to greater vulnerability as a result.

\section{The dilemma}

What developing countries know largely determines how they develop (Hamel, 2004). Beyond doubt, the scientific development of developing countries with their already restricted budgets has become more insignificant with the increasing prices of scientific resources. Tola (2003) suggests that poor countries should be guaranteed the right to have 
free access to scientific publications in order to slow down the asymmetric scientific development between developed and developing countries. However, this right has recently been denied mainly because of the increasing subscription costs. The distribution of paper copies of journals is expensive and requires extensive logistical infrastructure. Therefore digital provision may be more suited to the needs of developing countries because it is cheaper and more immediate. However, electronic publishing in some developing countries is not only seen as an opportunity but as a challenge, despite persistent problems of infrastructure, connectivity, resources, etc. Indeed, it has been recognised by scholars in these countries as an interesting and powerful tool to overcome some of the weaknesses of local journal publishing (Cetto, 2001).

\subsection{Opportunities}

The provision of free and low-cost access to scientific publications for institutions and researchers in developing countries will continue to be a significant aspect of the way they conduct their businesses. Online knowledge has distorted geography by shrinking distances and removing access barriers. Networking (subscribing to focused knowledge content), specialised forums, interest groups, and e-Conferences offer extraordinary means for knowledge transfer and partnership. In a recent paper by UNECA, Hamel (2004) argues that online or e-knowledge is the best thing ever to happen to African nations. Indeed, the internet provides a bonanza of knowledge. It is the new revolutionary instrument for accessing knowledge. Knowledge portals and online knowledge searching and knowledge sharing have grown fast and have considerably broken the isolation of most developing countries. Weerawarana and Weeratunga (2004) argue that developing countries in particular, with the resource constraints they face, view open source as a means of reducing the cost of IT investment and increasing its productivity. The imperative to adopt open source in these countries particularly in the public sector is also motivated by a desire for independence, a drive for security and autonomy, and a means to address intellectual property rights enforcement.

Scientists in developing countries can now freely access hundreds of scientific and professional journals, papers, documents, encyclopedias, reports, presentations, and lectures. This represents a considerable progress in comparison with the situation prevailing only a few years ago. Still today, the electronic and print versions of journals are not necessarily equivalent, and there are good reasons for making them different. However, according to Cetto (2001), most actors in the world of scholarly documentation (authors, editors, librarians, and readers) seem to agree that the printed copy is still useful and should be kept for a long period of time (if not forever), whilst the electronic version has become essential and should be used also to develop new services for end users. However, there are several successful examples (initiatives) that demonstrate such opportunities for the developing countries (for more details and examples, see STC, 2004; Hamel, 2004; The Wellcome Trust, 2003):

- The Health Inter-Network Access to Research Initiative (HINARI) provides free or nearly free access to the major journals in biomedical and related social sciences to public institutions in developing countries. The scheme incorporates over 2000 journals from 28 publishers, including: Blackwell, Elsevier Science, the Harcourt Worldwide STM Group, Wolters Kluwer International Health and Science, Springer Verlag, and John Wiley. Public institutions in two lists of countries, based on GNP 
per capita, can sign up for HINARI. Institutions in countries with GNP per capita below $\$ 1000$ are eligible for free access to the literature. Institutions in countries with GNP per capita between \$1000-\$3000 are eligible for access at reduced prices.

- The Access to Global Online Research in Agriculture (AGORA) scheme, sponsored by the Food and Agriculture Organization of the United Nations, and launched in October 2003, provides access to more than 400 key journals in food, nutrition, agriculture and related biological, environmental, and social sciences.

- The International Network for the Availability of Scientific Publications (INASP) is a cooperative network of partners, established in 1992, aiming to improve worldwide access to information. Its Programme for the Enhancement of Research Information (PERI) provides access to over 5000 full-text online STM, social science, and humanities journals.

- Researchers of the Forestry Research Institute of Malawi, part of the University of Malawi, currently have only very limited print journal resources. The internet has the potential to vastly increase the number and range of journal articles available to them but they are unable to afford subscription charges.

- An initiative called the Biological Innovation for Open Society (BIOS) is being established with a \$US1 million grant from the Rockefeller Foundation, to make research tools more readily available to biologists who could not otherwise afford them. BIOS is initiating an 'open source movement' in biotechnology, with an international community of interested researchers. Plant scientists in developing countries often complain that they are shut-off from recent advances in agricultural biotechnology because they cannot afford licensing fees. The initiative's first activities will be to gather a portfolio of research tools that can be used for free and to construct an easy-to-use database of patent information. Users, in turn, will be obliged to freely release innovations based on these technologies. The initiative's initial portfolio of research tools will include a new method for transferring genes into plants using modified bacterial species. ${ }^{5}$

- In 2001, a group of six US and European publishing companies announced that they would provide free, or at drastically reduced cost, electronic access to nearly 1000 medical journals to developing nations including most of SSA countries. Led by the World Health Organisation, the medical journals initiative will benefit nearly 600 institutions, including medical schools, research laboratories, and government health departments in developing countries, mostly in Africa. The programme will offer training to enable researchers to properly access the medical information by computer. In a related development, the Massachusetts Institute of Technology (MIT) officials have reported that their April (2001) decision to post virtually all of the course materials from MIT classes for free on the internet sparked an overwhelming response from students and college faculty in developing countries. "We got 4000 e-mails initially, most of which were international, thanking us for making this commitment", says MIT spokesperson Patti Richards.

- With the support from Industry Canada, UNECA has set up an African regional ePol-Net node to channel demand from African institutions and individuals, such as policy experts, programme managers, and legislative drafters seeking e-strategy expertise. The node was officially launched on 13 May 2003 and in order to 
determine the extent to which ICTs are used by African governments, UNECA conducted a survey, which shows that e-government is indeed taking root in the region. By June 2002, there were about 706 websites representing African public institutions. Analysis of the sites shows that Morocco, Egypt, Nigeria, Kenya, Mozambique, Mauritius, and South Africa have the highest number of websites. South Africa leads the group with 138. Also, countries with the highest government sites have a large number of internet users. Clearly, a critical mass of internet users is needed to increase the effectiveness of e-governments in Africa. Another example in Africa is set up by the African Agricultural Technology Foundation to remove many of the barriers that have prevented smallholder farmers in Africa from gaining access to existing agricultural technologies that could help improve food security and reduce poverty. The Foundation is dedicated to identifying and facilitating royalty-free acquisition of proprietary knowledge and technologies through negotiation and entering into contractual agreements with existing institutions that will manage deployment of the technologies and the related technical knowledge. Good governance needs to support these kinds of initiatives and foster open-access knowledge.

\subsection{Challenges and threats}

Despite all these exciting initiatives (opportunities) discussed earlier, there are many strategic challenges and serious concern that digital journals are inaccessible to developing countries as they simply do not have the technological infrastructure to receive and distribute them effectively. Weak communication and social infrastructure not only block information flows in most developing countries but ultimately stifle social and economic development. Weerawarana and Weeratunga (2004) argue that the critical factor for open-source and open-access publishing is the ability to become part of the internet as their development occurs primarily via e-mail communication and shared repositories published on the internet. Whilst $90 \%$ of internauts are in industrialised countries, 57\% of them in North America (USA and Canada), barely 1\% are in Africa and the Middle East. We should not forget that internet connection still requires a telephone line, and at least $80 \%$ of the world population does not have access to one. In most developing countries there is less than one line for every 100 inhabitants, and most of these countries are in Africa with a 3.5 years average waiting time for a telephone connection (World Bank, 2000a-b). Also the Bandwidth (International bandwidth in bits per capita is the new measure of internet use, shows how a country is progressing towards an information-based economy) availability in developing countries varies tremendously but is generally very low. If high-bandwidth internet access is not widely available in universities, companies, and individual homes, the ability to participate in open-access activities is severely limited. Therefore, accessibility to the worldwide network is not surprisingly very low in most developing countries (see Table 3).

However, the STC (2004) report argues that the relatively low levels of ICT in the developing world comparative to the West is not an argument against digital journals; rather, it highlights the need for further development of ICT capacity to fully exploit the potential of digital technologies. According to Sir Crispin Davis (STC, 2004) the movement to a digital-only environment would have the result of reducing accessibility to scientific research because it is only available on the internet and globally it would exclude over $50 \%$ of scientists. 
Table 3 Internet users (per 1000 people): people with access to the worldwide network

\begin{tabular}{lc}
\hline World regions & Internet users (2002) \\
\hline Sub-Saharan Africa & 9.6 \\
South Asia & 14.9 \\
Arab States & 28 \\
East Asia and the Pacific & 60.9 \\
Latin America and the Caribbean & 81.2 \\
All developing countries & 40.9 \\
Central and Eastern Europe & 71.8 \\
OCED & 383.1 \\
High-income OCED & 450.5 \\
World & 99.4 \\
\hline
\end{tabular}

Source: UNDP/HDR (2004)

There are also concerns that, by transferring the costs of the system from readers to authors in the developing world, the author-pays model would reduce the visibility of research generated there because of the inability of many authors to pay the publication fee. According to Blackwell Publishing (STC, 2004), the author charge is a barrier to publication which will favour richer countries and organisations and will make it difficult to publish a journal with authors from the developing world. Financial constraints on widespread use of the internet are also evident. In several countries in developing countries, university authorities give restricted net access to heads of department or senior staff via shared terminals 'because dial-up access is expensive' (Lund, 1998).

Cetto (2001) adds other obstacles and constraints that make electronic archiving and preservation of scientific material a still unresolved issue, such as: the nonexistence of some relevant titles in electronic form, the lack of technical support and reliable electronic infrastructure, and the uncertainty faced by libraries and end users about future access - even to previously paid subscriptions. Under such circumstances, the transition from the paper to the digital world sounds hardly realistic.

In a networked world, the opportunity cost and risk for a developing country lacking sophisticated IT capabilities and means of effective interaction with the global economy could be substantial, with growth and development being seriously affected (Weerawarana and Weeratunga, 2004). Thus, decisions governments make relating to IT strategy and policies broadly, and in particular to procurement, the setting and adoption of standards, investment in technology, and training and skill development can have grave consequences to the future well-being of their peoples.

Furthermore, the lack of Intellectual Property (IP) law framework and enforcement is a common symptom in developing countries as many countries simply failed to enforce IP laws. The result of course has been rampant pirating of proprietary software, thereby creating a false reality of wide availability of proprietary products at no cost. For example, it is common for a new computer to be pre-installed with pirated copies of whatever proprietary software the customer wants. In addition to being illegal, such piracy devalues the economic benefits of open-source products by falsely reducing the price of proprietary software. The economic benefit of open-source products will not be felt until IP is properly protected (for more details, see Weerawarana and Weeratunga, 2004). 
Another challenge in most developing countries is issues regarding Freedom of information. Access to the internet brings with it free access to information and therefore if the political climate of the country does not permit such access (like in most developing countries), then open source cannot succeed in that country.

\subsection{Requirements}

In order for open-source activities to proceed down a strategic path, certain IT infrastructural and skills conditions need to be met. These requirements include the following (for more details, see World Bank, 2000a-b; 2003a-b; 2004; 2005a-b; Weerawarana and Weeratunga, 2004):

- A network of training/educational institutions that teach basic computing skills is essential to promulgate the dissemination of open-access products and solutions. Higher level institutions that teach software development technique and technologies are also critical.

- As English undoubtedly remains the language for computing, good communication skills in English are therefore a critical tool of a successful open-source developer. Eventually, success in open-source development comes from having skilled developers. If the country does not have a skilled or trainable developer pool, then it is not feasible to succeed in these new development activities. It is of course still viable to execute other aspects of the open-access strategy.

For a country to be considered strong in IT infrastructure and skills, it is critical to have all these criteria satisfied to some extent - in particular, a strong IP law framework, good internet access, excellent education infrastructure, and English-speaking and skilled developers. Unfortunately, the reality is that most developing countries are weak in some or all of these essential requirements.

\section{The way forward....}

New technologies will continue to have an impact on the way scientists communicate amongst themselves and with other people. But, as has also been evident along the discussion in the present text, external conditions that determine the evolution of science, its structure, its institutional arrangements, and its relation with society are influencing the pace and the modalities of the transition to the electronic format. Amongst these conditions, perhaps the most salient one is the present scenario of disparities and differences within and between countries, which should be seriously considered in any strategic discussion on the future of electronic publishing and communication in science (for more details and examples, see Cetto, 2001).

Given the high cost involved in the publishing process (traditional or open access) and the difficulty of securing adequate funding as discussed earlier, there is an urgent need to find appropriate and effective solutions. Certainly, technology can be one of these solutions (attempts) to minimise publishing cost. Although several technological solutions are currently available to reduce the cost of publishing articles, most publishers use the traditional workflow for producing articles with solo focus on offshore outsourcing to reduce the cost of publishing. A revolutionary change to the entire 
production cycle using a structured database workflow and files optimisation will result in enormous saving to the cost of both printed and hosted journals. The following five key areas (appropriate technologies) have been identified for potential saving.

\subsection{Data structuring and production cycle}

Technologies such as Extensible Markup Language (XML) can be used in isolating article data from the presentation of that data. Publishers would be able to implement common framework whereby the production cycle of a journal will be completed using common platform, i.e., the author of an article will produce his article in XML extractable format using ready-made templates. The same template will be used throughout the production cycle then automatically plugged into the desired hosting platform. In addition to the saving in the data conversion process, using a web-based platform based on the same methodology will increase the overall efficiency in the production cycle and other e-publishing-related activities such as data propagations.

\subsection{PDF formatting}

PDFs are widely used in e-publishing as a method of delivery due to the ease of screen reading and printability. Unfortunately, most of the currently hosted PDFs are not optimised to the maximum level, and this results in oversized files that take longer to download, which leads to bandwidth wastage, i.e., the same bandwidth can be used to download more articles and/or two computers can download different articles using the same bandwidth during the selected time periods. This is one of the key problems faced by many developing countries.

\subsection{Standard publishing and e-publishing migration}

Vertical merger of the workflows to produce both electronic and hard copy can produce massive saving, as structured data can be used to produce electronic format (HTML) using technologies such as Extensible Stylesheet Language Transformation (XSLT) and to produce PDFs using technologies such as XSL-FO (XSL Formatting Objects).

\subsection{Automated workflow using latex}

Latex is a good example of cost saving using automated workflows. Latex is used by scientific researchers for submitting articles within the area of mathematics and physics, where the authors are required to submit papers using a special software to integrate the article to the publisher's production cycle. Latex is used by number of publishing organisations such as Taylor and Francis and the IEEE. Although Latex is beneficial for certain groups of authors (in physics and mathematics, etc.), the majority of authors within the other fields find it difficult to use.

\subsection{Standardisation across the publishing community}

Using a common standard in terms of template usage and other production-related activities will result in horizontal merger of production-cycle practices. This will further reduce the cost of publishing and e-publishing and may lead to the rollout of the functionality of typesetters from the entire operation. In addition, massive savings will be made to the data analysis phase in hosting projects. 


\section{Conclusion}

As the world shrinks and globalisation becomes an increasingly important determinant of the economic, social, and political conditions in countries and regions around the world, simple pragmatism would imply a need for greater cooperation on a global scale. The penetration of ICTs into the technoscientific world, including groupware and telephony, is accompanied by the development of skills amongst researchers, which makes working across geographical distances and timezones increasingly effective.

The current system of scholarly publishing has become too costly for the academic community to sustain. The increasing volume and costs of scholarly publications, particularly in STM, are making it impossible for libraries and their institutions to support the collection needs of their current and future faculty and students. However, the lack of consensus and concerted action by the academic community continues to allow the escalation of prices.

The publishing monopoly has very important adverse effects on the society especially considering the developing countries, which cannot possibly afford to buy the knowledge due to their budgetary constraints. Furthermore, journal price restrictions will come to undermine the economic development efforts of developing countries unless the model is changed into an open-access publishing model. Therefore, looking at the barriers on entry to publishing business as well as the restrictions on accessing and transferring scientific knowledge, the open-access model is seen to be the only way of breaking the publishing monopoly.

Governments' support is necessary, particularly in developing countries, to build the required infrastructure for open-access publishing. Also, research-oriented institutions should be able grant some funds to offer free access to their readers. This model can be feasible in the sense that governments already pay large sums for $R \& D$, and open-access model can be seen as an extension of $R \& D$ investments for transferring the outcomes of the conducted research to the society. Institutions should also be willing to contribute to the financing of the model as they already pay subscription fees for their readers in larger amounts.

Scholars should also take action to facilitate the open-access publishing model and maybe reject to publish in journals that refuse to adapt to this model and reject to peer review for such journals. However, financing of the open-access publishing model by the authors should not be promoted since paying for publishing may possibly have undesired impacts on the faculty. Whereas researchers in developing countries need access to as large a proportion of global research output as possible, the proportion of published articles originating in such countries is currently very small. In addition, many research projects in the developing world are either funded by or carried out in collaboration with partners in developed countries that can afford to pay publication charges.

\section{Acknowledgement}

I am grateful to Engineer Mohamed Elhag, Electronic Editor for WRSTSD and WREMSD for his invaluable contribution and helpful notes in Part 6 of the paper (The way forward...). 


\section{References}

Ahmed, A. (2004) 'Making technology work for the poor: strategies and policies for African sustainable development', International Journal of Technology, Policy and Management, Vol. 4, No. 1, pp.1-17.

Arunachalam, S. (2000) Debates on Issues of Our Common Future, in W. Krull (Ed.) Velbrück, Volkswagen Found.

Castells, M. (1998) End of Millennium, Oxford: Blackwell.

Cetto, M.A. (2001) 'The contribution of electronic communication to science - has it lived up to its promise?', Proceedings of the Second ICSU-UNESCO International Conference on Electronic Publishing in Science, Paris: UNESCO House, 20-23 February.

Dunn, J. (1982) Identity, Modernity and the Claim to Know Better, HSDRSCA-103/UNUP-441, Tokyo: The United Nations University.

Eisemon, T.O. and Davis, C.H. (1991) 'Can the quality of scientific training and research for the participation of developing countries scientists in mainstream science be improved by training', Minerva, Vol. 29, No. 1, pp.122-131.

Frazier, K. (2001) 'The librarien's dilemma: contemplating the costs of the "big deal"', D-Lib Magazine, ISSN 1082-9873, Vol. 7, No. 3.

Gibbs, W.W. (1995) 'Lost science in the third world', Science in America, pp.92-99,273.

Goldemberg, J. (1998) 'What is the role of science in developing countries?', Science, pp.279,1140-1141.

Hamel, J.L. (2004) 'Knowledge policies for sustainable development in Africa: a strategic framework for good governance', Draft Working Paper, UNECA/SDD, Addis Ababa, October, p.54.

Lund, H. (1998) 'Bridging the gap?', Commonwealth Higher Education Management Service, September.

McCabe, M.J. (2002) 'Journal pricing and mergers: a portfolio approach', The American Economic Review, March, Vol. 92, No. 1.

McCabe, M.J. (2004) 'Information goods and endogenous pricing strategies: the case of academic journals', Economics Bulletin, Vol. 12, No. 10.

MacLeod, D. (2005) 'Academics fight to break "stranglehold" on journals', The Guardian, 26 January, http://education.guardian.co.uk/higher/sciences/story/0,12243,1398368,00.html.

May, R.M. (1997) 'The scientific wealth of nations', Science, pp.275,793-796.

Page, G., Campbell, R. and Meadows, J. (1997) Journal Publishing, UK: Cambridge University Press.

Porter, M.E. (1990) The Competitive Advantage of Nations, New York: The Free Press.

Riddoch, I. (2000) 'Bridging the quality gap', Nature, pp.402,408.

Savenije, J.S.M. (2003) 'Recent developments in commercial scientific publishing: an economic and strategic analysis', DF Revy, Vol. 26, No. 8, pp.220-227.

Science and Technology Committee (STC) (2004) 'Scientific publications: free for all?', Tenth Report of Session 2003-04, Volume I: Report, HC 399-I, House of Commons Science and Technology Committee, London: The Stationery Office Limited.

Shulenburger, D.E. (2001) 'Principles for a new system of publishing for science', Proceedings of the Second ICSU-UNESCO International Conference on Electronic Publishing in Science, Paris: UNESCO House, 20-23 February.

Suber, P. (2005) Timeline of the Open Access Movement, http://www.earlham.edu/ peters/fos/ timeline.htm (accessed 15 April 2005).

Tenopir, C. and King, D.W. (2000) Towards Electronic Journals: Realities for Scientists, Librarians, and Publishers. Special Libraries Association 2000, ISBN 0-87111-507-7, Vol. xxii, p.488. 
The Wellcome Trust (2003) Economic Analysis of Scientific Research Publishing: A Report Commissioned by the Wellcome Trust, The Wellcome Trust.

Tola, E. (2003) 'Hinari and Agora: free access to scientific information for poor countries', Journal of Science Communication (JCOM), ISSN 1824-2049, December, Vol. 2, No. 4, http://jcom.sissa.it/focus/foc020403_or.html.

UK Department of Trade and Industry (UKDTI) (2002) 'Publishing in the knowledge economy competitiveness analysis of the UK publishing media sector', Main Report, London, UK, http://www.dti.gov.uk.

United Nations Commission for Science and Technology (1998) Knowledge Societies Report, United Nations Commission for Science and Technology.

United Nations Development Programme (UNDP) Human Development Report (HDR) (2004) Cultural Liberty in Today's Diverse World, United Nations Development Programme, Human Development Report, http://hdr.undp.org/statistics/data/indic/indic_115_3_2.html.

United Nations Educational, Scientific and Cultural Organization (UNESCO) (1992) UNESCO Statistical Yearbook 1991, Paris: UNESCO.

United Nations Educational, Scientific and Cultural Organization (UNESCO) (2001) The State of Science and Technology in the World, UNESCO: Institute of Statistics.

United Nations World Summit on the Information Society (2003) Declaration of Principles and Plan of Action, http://www.itu.int/wsis/documents/doc_multi.asp?lang=en\&id=1161|1160.

Vinay, K. and Saran, R. (1998) 'The best cities 1998', Business Today, Living Media India Ltd., 22 December.

Walsham, G. (2000) 'IT/S in developing countries', in M. Zeleny (Ed.) The Handbook of Information Technology in Business, International Encyclopedia of Business Management. Thomson Learning, ISBN 1-86152-308-4, London, UK, pp.105-109.

Weerawarana, S. and Weeratunga, J. (2004) Open Source in Developing Countries, The Swedish International Development Cooperation Agency (Sida), ISBN 91-586-8613-4, http://www.sida.se/publications.

World Bank (2000a) African Development Indicators, Washington, DC: World Bank.

World Bank (2000b) 'Can Africa claim the 21st century?', The International Bank for Reconstruction and Development, Washington, DC: World Bank.

World Bank (2003a) 'Global economic prospects: realizing the development promise of the Doha agenda', The International Bank for Reconstruction and Development, The World Bank, Washington, DC: World Bank.

World Bank (2003b) World Development Indicators (WDI) 2003, Washington, DC: World Bank.

World Bank (2004) World Development Report 2004: Making Services Work for Poor People, Washington, DC: World Bank.

World Bank (2005a) Global Agricultural Trade and Developing Countries, Washington, DC: World Bank, http://publications.worldbank.org/ecommerce/catalog/product?item_id=3829969.

World Bank (2005b) World Development Report 2005: A Better Investment Climate for Everyone, Washington, DC: World Bank, http://publications.worldbank.org/ecommerce/catalog/product? item_id=3043503.

\section{Bibliography}

Bethesda Statement on Open Access Publishing (2003) Bethesda Statement on Open Access Publishing, http://www.earlham.edu/ peters/fos/bethesda.htm.

Bryne, A. (2003) Necromancy or Life Support? Libraries, Democracy and the Concerned Intellectual, Library Management, Vol. 24, No. 3.

Eisemon, T.O. and Davis, C.H. (1991) Can the Quality of Scientific Training and Research in Africa Be Improved by Training, Minerva, Vol. 29, No. 1. 
Gast, A. (2002) The Impact of Restricting Information Access on Science and Technology, Available at http://www.aau.edu/research/Gast.pdf.

Internetworldstats (2004) Internet Usage Statistics - The Big Picture (Worldinternet Users and Population Statistics, January 2005).

Suber, P. (2002) 'Open access to the scientific journal literature', Journal of Biology, Vol. 1, p.1.

United Nations (UN) (2002) 'Implementation of the United Nations millennium declaration', Report of the Secretary-General. United Nations General Assembly, 32 July, http://www.un.org.

United Nations Development Programme (UNDP) Human Development Report (HDR) (1999) Chapter on New Technologies and the Global Race of Knowledge, United Nations Development Programme, Human Development Report.

United Nations Economic Commission for Africa (UNECA) (2003) E-Strategy, Addis Ababa, Ethiopia.

\section{Notes}

1 Public Library of Science (PLoS), website www.plos.org

2 Joint Information Systems Committee, http://www.biomedcentral.com/

3 United States Congress Public Access to Science Act, http://thomas.loc.gov/cgi-bin/query/z? c108:H.R.2613

4 Berlin Declaration on Open Access to Knowledge in the Sciences and Humanities, http://www.zim.mpg.de/openaccess-berlin/berlindeclaration.html

5 Science and Development Network (SciDevNet), http://www.scidev.net/news/index.cfm? fuseaction=readnews \&itemid $=1636 \&$ language $=1$ 